\title{
Limites Constitucionais Relativos à Prova na INVESTIGAÇÃo Criminal
}

EMERSON Silva BARBOSA

Departamento de Polícia Federal - Brasil

$$
\text { ○浆亏 }
$$

\begin{abstract}
RESUMO
Trata-se de trabalho que busca expor e discutir os limites constitucionais relativos à prova no processo penal brasileiro. A intenção aqui é abordar os problemas decorrentes da licitude da prova sob a perspectiva negativa - da proibição de uso de prova ilícita. Desse modo, pretendemos abordar o problema da obtenção da prova em situações que requerem o afastamento de direitos fundamentais, tais como a intimidade ou privacidade e a integridade corporal.
\end{abstract}

Palavras-Chave: Prova; Prova ilícita; Devido processo penal.

\section{INTRODUÇÃ̃o}

Tratar sobre processo penal em um Estado democrático de direito não é, certamente, tratar de qualquer tipo de processo, mas de um procedimento destinado a resolver conflitos de interesses fundado em preceitos garantistas de racionalidade e justiça, mesmo que isso importe em se reconhecer um obstáculo à obtenção da verdade. Por um lado, um processo em que os atores institucionais compartilham critérios éticos de obediência à legalidade e às regras procedimentais. De outro, um processo que para além da observância firme da lei, também está sujeito a um conjunto de direitos e garantias que assegurem um equilíbrio entre o poder do Estado e o investigado consubstanciados, sobretudo, em vedações no tocante à prova - meios de obtenção da verdade - e na possibilidade de ampla refutação das imputações a ele dirigidas ${ }^{1}$.

No âmbito do processo penal, a regra vigente é a da liberdade probatória - princípio da investigação integral ${ }^{2}$-, que consiste na compreensão de que no processo o fato pode ser provado (no sentido de existência

1 Nesse sentido, ver Ferrajoli (2002); Barbosa (2011).

2 Expressão utilizada por Rossi (apud Correa, 2006). 
ou inexistência) por qualquer meio de prova legítimo. Entre as principais justificativas para isso estão: a) o princípio da livre convicção motivada; b) a constatação empírica de que não há prova perfeita; e c) o contraditório.

Em primeiro lugar, toda prova é apta a formar a convicção do juiz sobre o fato a ser provado, seja em benefício da acusação ou da defesa (a). Com isso, tanto as partes como o órgão julgador têm à sua disposição o poder de buscar, por meio de diligências diretas ou por solicitação/requisição, as provas que entenderem necessárias e suficientes à demonstração fática e jurídica da verdade processual.

Em segundo lugar, reconhece-se que nenhuma prova é, por si mesmo, superior a outra (b). Diante disso, repudia-se qualquer sistema que preveja a hierarquização ou tipologias de provas, possibilitando-se, assim, uma maior liberdade na busca dos meios mais eficazes e menos custosos para a comprovação do fato (BARBOSA, 2011a).

Em terceiro, não se pode falar em processo justo sem o necessário jogo dialético de provas e contraprovas objetivando confirmar ou refutar os fatos aduzidos pelas partes. Desse modo, ao se tarifar determinada prova há um claro prejuízo à dialética processual e à obtenção da verdade ${ }^{3}$ (BARBOSA, 2011b).

Contudo, é preciso atentar para o fato de que a busca da verdade processual atingível, dita equivocadamente real ${ }^{4}$, não é ilimitada. Além de se submeter a condicionamentos físicos ou circunstanciais (intervenções humanas ou de eventos naturais) que podem impedir o acesso ao conhecimento a respeito de fatos, a Constituição e as leis impõem limites à atividade probatória, seja vedando o uso de elementos de prova ${ }^{5}$ obtidos ilicitamente (confissão mediante tortura, por exemplo), seja impondo determinados tipos ou meios probatórios específicos (obrigatoriedade de realização de exame de corpo de delito).

3 É o caso no Brasil, por exemplo, da obrigatoriedade do exame de corpo de delito. Sobre isso, ver Barbosa (2012).

4 Grinover (apud Correa, 2006) chama a atenção para distinção entre verdade material e judicial. Segundo esta autora, o resgate ao sentido correto do termo verdade material nos leva à verdade não influenciada pelo comportamento processual das partes; enquanto que verdade judicial seria a verdade obtida a todo custo, não limitada. Ressalta-se, porém, que os termos verdade real ou material são comumente empregados com o sentido de reconstrução histórica dos fatos como eles se sucederem.

5 Elemento de prova, ou prova propriamente dita, na feliz síntese de Mariconde (p. 314 apud Cafferata Nores, 1998, p. 30) "es todo dato objetivo que se incorpora legalmente al proceso, capaz de producir un conocimiento cierto o probable acerca de los extremos de la imputación delictiva”. 
Assim, a aptidão da prova para demonstrar que algo é verdadeiro não diz respeito apenas ao seu aspecto técnico, ou seja, a viabilidade do exame, mas, principalmente, a seu aspecto jurídico (viabilidade jurídica). Por isso, a busca da prova não é ilimitada, seja pela impossibilidade física de convencer sobre a existência do fato histórico que se alega tenha ocorrido ${ }^{6}$, seja como consequência das limitações previstas nas leis e na Constituição que, em última análise, objetivam proteger direitos e liberdades essenciais do cidadão. Diante disso, faz-se necessário ter em vista que a atuação de toda instituição pública ou do particular na busca da prova deve estar fundada na eficácia, uma vez que o interesse pela verdade exige isso. Contudo, num Estado de Direito, não basta se alcançar a eficácia técnica ${ }^{7}$. É preciso, principalmente, assegurar a eficácia jurídica na atuação das instituições e das partes no processo penal. Em outros termos, as provas, além da validade técnica, devem também conter validade jurídica. A regra básica é a de que não se pode admitir o pagamento de qualquer preço para se chegar à verdade possível.

Consoante assevera Grinover (apud Correa, 2006, p. 20):

A legalidade na disciplina da prova não indica um retorno ao sistema da prova legal, mas assinala a defesa das formas processuais em nome da tutela dos direitos do acusado: as velhas regras da prova legal apresentavam-se como regras para a melhor pesquisa da verdade; seu valor era um valor de verdade. Hoje, bem pelo contrário, as regras probatórias devem ser vistas como normas de tutela da esfera pessoal de liberdade: seu valor é um valor de garantia.

$\mathrm{O}$ erro ou a infração de qualquer norma atinente às mencionadas questões importa não só no comprometimento da investigação criminal ou do processo penal (possível sentença condenatória), mas, em definitivo, no fracasso do Estado de Direito que, a todo momento, vê-se ameaçado pelo Estado de Polícia ${ }^{8}$ (COLOMER, 2004).

Por esta razão, a ideia aqui é verificar quais são os limites pertinentes à obtenção da prova no processo penal, tendo como parâmetros três meios de prova que maiores restrições impõem aos direitos fundamentais, quais sejam: a) o afastamento dos sigilos de dados; b) as interceptações telefônicas; e c) as intervenções corporais.

6 E que, hipoteticamente, suscita-se como delituoso.

7 A idéia de eficácia aqui também abrange a noção de eficiência.

8 Entende-se por Estado de Polícia aquele Estado autoritário que impõe discricionariamente sua vontade (e a sua verdade) sobre os cidadãos. 
O presente estudo tem por objetivo descrever e discutir as formas de obtenção da prova no processo penal brasileiro e seu o impacto sobre os direitos fundamentais, que convergem a um exame dos problemas decorrentes da licitude da prova sob a perspectiva negativa — da prova ilícita - seja pela ilicitude intrínseca da prova, seja como resultada da derivação de outra prova (meio de prova) ilícita.

\section{A Devida InVestigação Criminal Como Corolário do Sobreprincípio do Devido Processo Penal}

A Constituição da República Federativa do Brasil de 1988 - CRFB, em seu artigo $5^{\circ}$, inciso LIV previu expressamente o princípio do devido processo legal: "Ninguém será privado da liberdade ou de seus bens sem o devido processo legal".

A noção de devido processo legal corresponde, nos termos da dimensão atual que se empresta a esse princípio, à garantia de um processo justo $(\text { fair trial })^{9}$, não apenas em sentido formal, mas também material. Desse modo, para afetar a vida, a liberdade ou o patrimônio dos cidadãos, o Estado, por quaisquer de seus poderes constituídos deverá submeter sua demanda constritiva a um processo legítimo orientado não apenas por garantias formais derivadas da lei, mas, bem assim, assegurar que as regras jurídicas que limitam direitos sejam construídas (legisladas) e aplicadas (executadas) com base em rígidos critérios de racionalidade e razoabilidade ${ }^{10}$. As decisões jurídicas se legitimam, nesse sentido, por meio de um procedimento orientado por regras e princípios ${ }^{11}$.

9 A ideia de devido processo legal teria surgido, pela primeira vez, na Magna Charta Libertatum de 1215, sob a terminologia de law of the land, que tempos depois foi substituída pelo Parlamento Inglês pela expressão due processo of law (BULOS, 2009; MORAES, 2007). A cláusula do devido processo legal foi mais tarde assimilada pelos constitucionalistas norte-americanos e, em seguida, disseminouse pelas organizações políticas latino americanas, tornando-se garantia indispensável à salvaguarda dos direitos e liberdades fundamentais contra o arbítrio dos poderes estatais.

10 Adota-se aqui o como sinônimas as expressões razoabilidade e proporcionalidade, por entender que ambas têm a mesma raiz epistemológica.

11 Como assevera Bulos (2009, p. 288): “A relevância do devido processo legal exsurge, inclusive, no embate entre o interesse particular e os interesses da comunidade. O primeiro só prevalece quando houver a comprovação de sua imperatividade (compeling interest). Haverá, então, a inversão do ônus da prova. O indivíduo afrontado em seus direitos fundamentais poderá invocar a tutela de suas prerrogativas. Quanto ao Estado, compete-lhe provar a inexistência daquele interesse imperativo da comunidade, para o ato legislativo ou executivo não violar a Constituição". 
Ressalta-se que a garantia do devido processo legal é uma das mais abrangentes e relevantes garantias do direito constitucional, sobretudo quando o que está em jogo é a administração da justiça criminal. Por isso, tem-se emprestado à referida cláusula constitucional um status de sobreprincípio, uma vez dela derivam uma série de garantias processuais hoje especificadas no artigo $5^{\circ}$ da Constituição brasileira. Entre elas podemos citar:

a) isonomia (art. $5^{\circ}$, caput e I);

b) contraditório e a ampla defesa (art. $\left.5^{\circ}, \mathrm{LV}\right)$;

c) direito ao juiz natural (art. $\left.5^{\circ}, \mathrm{LIII}\right)$;

d) direito a não ser processado e condenado com base em prova ilícita (art. $\left.5^{\circ}, \mathrm{LVI}\right)$;

e) direito a não ser preso senão por determinação da autoridade competente e na forma estabelecida pela ordem jurídica (art. $\left.5^{\circ}, \mathrm{LXI}\right)$;

f) publicidade dos atos processuais (art. $5^{\circ}, \mathrm{LX}$ e art. 93, IX);

g) motivação das decisões judiciais (art. 93, IX);

h) inafastabilidade do controle jurisdicional ou do direito de ação $\left(\right.$ art. $\left.5^{\circ}, \mathrm{XXXV}\right) .^{12}$

Além disso, o princípio do devido processo legal aplicável ao processo penal - por isso fala-se em devido processo penal —é também um tipo de garantia subsidiária e geral em relação às demais garantias constitucionais de índole penal. Em outras palavras, garantias como inadmissibilidade do uso de prova ilícita no processo ou a de não ser preso senão por ordem de autoridade competente são desdobramentos do princípio central do devido processo penal (MENDES et. al., 2010).

Como mencionado, uma das garantias mais importantes decorrentes do sobreprincípio do devido processo legal é a inadmissibilidade do uso

12 Alguns autores elencam outros, ainda que implícitos como os princípios do promotor natural, razoabilidade, proporcionalidade e do duplo grau de jurisdição (BULOS, 2009). 
da prova ilícita ${ }^{13}$ no processo penal ${ }^{14}$. A expressão processo aqui deve ser entendida em sentido amplo, isto é, deve abranger não apenas como instrução judicial, mas também o inquérito policial ou qualquer outro procedimento preliminar de instrução, a fim de não deixar desamparado o investigado (BULOS, 2009). Nesse sentido, a garantia da inadmissibilidade das provas ilícitas é um limite imposto também ao poder investigatório do Estado, a fim de que ninguém seja investigado e processado com base em elementos probatórios obtidos ou produzidos de forma ilícita. Por esta razão, pode-se falar também na garantia da devida investigação criminal como corolário do sobreprincípio do devido processo legal ${ }^{15}$.

Uma devida investigação criminal reivindica, a meu ver, entre outras coisas: a) uma clara compreensão da existência de limites contra epistemológicos no processo que objetivam assegurar valores essenciais; b) que a coleta de dados e inquirição de pessoas seja orientada pela legalidade e proporcionalidade de meios, técnicas e recursos disponíveis ao investigador ${ }^{16}$; ) um rígido sistema de controle, acompanhamento e responsabilização capazes,

13 Em igual sentido: A cláusula constitucional do due process of law encontra, no dogma da inadmissibilidade processual das provas ilícitas, uma de suas mais expressivas projeções concretizadoras, pois o réu tem o direito de não ser denunciado, de não ser processado e de não ser condenado com apoio em elementos probatórios obtidos ou produzidos de forma incompatível com os limites éticojurídicos que restringem a atuação do Estado em sede de persecução penal. [...] A prova ilícita - por qualificar-se como elemento inidôneo de informação - é repelida pelo ordenamento constitucional, apresentando-se destituída de qualquer grau de eficácia jurídica”. (STF - RE 251.445-4-GO Relator: Ministro Celso de Mello - DJU de 03/08/2000 - p.68).

14 No tocante à ilicitude da prova, esta pode afetar tanto as regras de produção ou obtenção da prova, como também o próprio conteúdo da prova, isto é, podem ser produzidas ou obtidas sem a observância dos meios previstos em normas procedimentais ou, embora sigam os meios legítimos de obtenção, atentem contra direito individual assegurado em lei.

15 Assinalaria, ademais, na linha que defende Rogério Tucci (2009), no tocante à investigação criminal, o sentido do devido processo legal engloba ainda três postulados essenciais: inadmissibilidade de sujeição à persecução penal sem que tenha ocorrido um fato típico, antijurídico e culpável e a consequente existência de indícios de autoria; vedação à coerção direita, sendo necessária judicialização do fato delituoso com vista a aplicação de pena ou medida de segurança; a inviabilidade de aplicação antecipada, provisória ou definitivamente, da sanção penal antes do transito em julgado da sentença penal condenatória.

16 Cumpre ressaltar, porém, que as regras que regulam e limitam a obtenção, produção e a valoração das provas, em que pesem dirigidas mais fortemente às instituições oficiais de persecução, no intuito de proteger os direitos fundamentais do indivíduo atingido pela persecução penal, em um sistema processual democrático, em que há uma ativa participação da defesa no processo, particularmente no que diz respeito à atividade probatória, as vedações à utilização de prova ilicitamente obtida devem também ser a ela aplicadas. No Brasil, a participação probatória da defesa (investigação defensiva) ainda não é realidade. Na medida em que a instrução preliminar é dirigida ao acusador público, há ainda uma resistência em se admitir a participação da defesa na produção de provas, mesmo de forma mitigada como a prevista no art. 14 do Código de Processo Penal. 
senão de eliminar, ao menos minimizar eventuais incorreções ou nulidades na instrução processual e expurgá-las quando necessário.

Por esta razão, veremos a seguir alguns aspectos da licitude da prova, enquanto garantia de justiça (e não de verdade) no processo penal, que se aplicam à persecução penal.

\section{Das Limitaçóes à Prova e a Prova (I)Lícita no Processo Penal}

Como já ressaltado, é possível identificar diferentes dimensões limitadoras das provas no processo penal e, consequentemente, do acesso à verdade material na persecução penal. Binder (1999, p.178), por exemplo, sustenta a existência de três níveis de limitação relativas à atividade probatória e, por consequência, de acesso à verdade. $\mathrm{O}$ primeiro nível é o das "proibições probatórias", que abrange um conjunto de campos, temas e métodos absolutamente proibidos, como tortura, ameaça e coação para obter confissão. No segundo nível, encontramos os requisitos de formalização e limitação de possibilidades para obtenção da informação, como aqueles casos submetidos à prévia autorização judicial expressa e específica, por exemplo, a busca e apreensão de documentos ocultos em domicílios, interceptação de comunicações telefônicas ou telemáticas, dados sigilosos etc. E, por fim, no terceiro nível, temos a "legalidade da prova", que condiciona o ingresso de informações no processo à observância de certas e determinadas formas previamente estabelecidas, o que resulta na proibição do ingresso de informações advindas de rumores, testemunhas anônimas, conhecimento privado de alguma autoridade investigatória ou do juiz etc.

A vedação ou limitação do uso de determinados meios de prova são, certamente, condicionantes do resultado que se poderá atingir com a investigação. Ou, ainda, nas palavras de Badaró (2003, p. 37): “(...) o grau de verdade, isto é, a maior ou menor aproximação da verdade, é determinado diretamente pela disciplina legal do procedimento probatório que se adote para a verificação dos fatos objetos do processo".

Referida limitação, decerto, não se restringe a delinear apenas formalidades que deverão ser cumpridas (p.ex.: exibição do mandado de busca e apreensão), que também têm o efeito de invalidar a prova produzida, mas, 
sobretudo, de impregnar a busca pela comprovação ou refutação da hipótese de um conteúdo axiológico que deve permear, entre outras coisas: a opção estratégica pelo método, a legitimidade do procedimento e a decisão pela admissibilidade ou não da prova.

Desse modo, é de admitir que a prova não seja tida por ilícita tão somente porque, em certos casos, houve uma infração penal (violação de domicílio, interceptação de comunicação telefônica, constrangimento ilegal etc.), mas por violar condicionamentos axiológicos condensados em preceitos fundamentais, tais como a proteção da intimidade, da privacidade ou a imagem (CAPEZ, 2007). A proteção penal é, portanto, conseqüência secundária no âmbito dessa relação Estado $\mathrm{x}$ indivíduo.

Como já dito a Constituição brasileira veda expressamente o uso da prova obtida ilicitamente nos processos judiciais (art. $\left.5^{\circ}, \mathrm{LVI}\right)^{17}$. Todavia, ao contrário da Constituição portuguesa que especifica os meios ilícitos de obtenção das provas - tortura, coação, ofensa à integridade física ou moral da pessoa, abusiva intromissão na vida privada, no domicílio, na correspondência e nas telecomunicações —, a Carta Constitucional brasileira não especificou os meios ilícitos de obtenção da prova. Nesse sentido, coube ao legislador infraconstitucional, à doutrina e à jurisprudência a tarefa de conectar a referida proteção constitucional com regras procedimentais e materiais derivadas ou não de outros direitos e garantias fundamentais, entre eles: a) direito a inviolabilidade do domicílio (art. $5^{\circ}, \mathrm{XI}$ ); b) o sigilo de correspondência e das comunicações telegráficas, de dados e das comunicações telefônicas (art. $5^{\circ}, \mathrm{XII}$ ); c) o direito ao sigilo profissional (art. $5^{\circ}$, XIII e XIV); d) protege o homem contra tortura e tratamento degradante (art. $5^{\circ}$, III) e assegura ao preso sua integridade física e moral (art. $5^{\circ}$, XLIX); e) não obrigatoriedade de fazer prova contra si mesmo: recusa a depor (direito silêncio) e a fornecer material gráfico ou DNA para exame pericial $^{18}$ (art. $5^{\circ}$, LXIII) (MENDES et. al., 2010).

A violação destas garantias individuais de natureza constitucional enseja a produção de prova ilícita no processo penal (FERNANDES, 2002).

17 Utilizaremos a expressão prova ilícita como expressão equivalente ao de prova proibida, vedada ou vedada que abrange tanto contrariedade a norma de conteúdo processual quanto material.

18 Acrescente-se o direito a não participar de reprodução simulada do evento delituoso, a realização de teste do bafômetro para mediação no nível de álcool no sangue etc. 
Ao Estado, por meio dos seus órgãos de persecução penal compete provar, licitamente, a existência do crime e quem seja o seu autor. Desse modo, verificado no âmbito da investigação criminal que a prova da materialidade do crime (p.ex.: entorpecente, documento), foi obtida mediante uma ação ilícita - interceptação telefônica clandestina, tortura, invasão de domicílio etc. - , há um comprometimento da instrução provisória e, consequentemente, da instrução judicial ${ }^{19}$.

Observa-se, todavia, que não são ilícitas tão-somente as provas diretamente obtidas, mas também as provas ilícitas por derivação ${ }^{20}$. Trata-se, como destaca Mendes et. al. (2010), uma construção da Suprema Corte americana que restou admitida em nosso direito, embora a efetiva derivação por ilicitude deva ser verificada no caso concreto.

O problema da prova ilícita por derivação afeta diretamente as investigações criminais, na medida em que, em regra, é no inquérito policial que são produzidas e/ou obtidas a maioria das provas pertinentes à comprovação da suspeita levantada (hipótese acusatória), ainda que sob a supervisão do Ministério Público - e do acusado em menor medida - e mediante controle do Poder Judiciário, nos casos em que a diligência importe em afetação a direitos fundamentais do investigado (liberdade, intimidade, patrimônio, integridade física etc.).

19 Ressalta-se que a obtenção de provas sem a observância das garantias previstas na ordem constitucional ou em contrariedade ao disposto em normas fundamentais de procedimento configurará, além de afronta ao princípio específico, lesão ao princípio do devido processo legal, o que autoriza a doutrina a afirmar a existência de uma superfetação. Cf. MENDES et. al., 2010. A superfetação pressupõe a proteção de um mesmo direito por regras jurídicas distintas, ensejando numa superposição de normas em face do mesmo tema.

20 Contudo, atualmente, referida doutrina tem sido objeto de mitigação a fim de evitar a impunidade, pela aplicação dos conceitos de provas autônomas ou independentes e em descobertas inevitáveis como exceções à proibição ao uso da prova derivada da prova ilícita (MENDES et. al., 2010). A reforma do Código de Processo Penal - CPP, realizada por intermédio da Lei $n^{\circ}$ 11.690/2008, enfatizou a tese das provas independentes e das descobertas inevitáveis. Dispõe o art. 157, caput, $₫ 1^{\circ}$ e $2^{\circ}$ do CPP: Art. 157. São inadmissíveis, devendo ser desentranhadas do processo, as provas ilícitas, assim entendidas as obtidas em violação a normas constitucionais ou legais. (Redação dada pela Lei n ${ }^{\circ}$ 11.690, de 2008)

$\S 1^{\circ}$ São também inadmissíveis as provas derivadas das ilícitas, salvo quando não evidenciado o nexo de causalidade entre umas e outras, ou quando as derivadas puderem ser obtidas por uma fonte independente das primeiras. (Incluído pela Lei no 11.690, de 2008)

$\$ 2^{\circ}$ Considera-se fonte independente aquela que por si só, seguindo os trâmites típicos e de praxe, próprios da investigação ou instrução criminal, seria capaz de conduzir ao fato objeto da prova. (Incluído pela Lei n ${ }^{\circ} 11.690$, de 2008). 
A obtenção de dados por meio da violação do sigilo fiscal ou bancário, a violação do domicílio e do sigilo telefônico sem autorização judicial para obtenção de evidências sobre o delito, como ações do Estado no exercício do seu direito de investigar, no âmbito no inquérito policial, não podem servir de elementos de convicção, nem para autoridade policial, nem para acusador (público ou privado), muito menos para juiz do processo ${ }^{21}$.

O vício na coleta dos vestígios do crime contamina até mesmo outros meios de prova, a exemplo do exame pericial. Cita-se como exemplo o caso de um exame sobre um documento supostamente falsificado obtido por meio de invasão domiciliar. A apreensão de documento em âmbito domiciliar sem autorização judicial específica quanto ao seu objeto e extensão, regra geral, contamina a força probatória do vestígio. Assim, a realização de um exame pericial sobre o corpo de delito, em que pese possa preencher os requisitos de validade técnica que possibilitem determinar a inautenticidade do documento, não é capaz de afastar o vício de validade (jurídica) verificado na origem de seu processo de produção/obtenção.

Em síntese, a proibição de utilização de determinados meios de obtenção de prova tem como objetivo, além de proteger os direitos fundamentais do cidadão, assegurar validade do material probatório a ser admitido e valorado no processo (OLIVEIRA, 2007). Destaca-se, porém, que, atualmente, referida postura tem sido objeto de mitigação, a fim de evitar a impunidade, pela aplicação dos conceitos de provas autônomas ou independentes e em descobertas inevitáveis como exceções à proibição ao uso da prova derivada da prova ilícita (MENDES et. al., 2010). A reforma do Código de Processo Penal - CPP, realizada por intermédio da Lei no 11.690/2008, enfatizou a tese das provas independentes e das descobertas inevitáveis.

Diante da problemática suscitada, passaremos a examinar os principais mecanismos de prova e dos problemas derivados da não observância estrita das regras de execução.

21 Com sustento no princípio da proporcionalidade e no equilíbrio entre os direitos fundamentais do cidadão e um processo penal justo e eficaz, por vezes os tribunais têm mitigado a vedação a utilização de provas ilícitas, desde que ela não seja o único elemento de convicção e que seja corroborada por outros elementos de prova no processo (BONFIM, 2009). 


\section{I. DIREITO À PRIVACIDADE: INTERCEPTAÇÕES TELEFÔNICAS, GRAVAÇÕES E QUEBRA DE SIGILOS DE DADOS FISCAIS, BANCÁ- RIOS, TELEFÔNICOS E DA CORRESPONDÊNCIA}

A Carta Constitucional de 1988 declara como invioláveis a intimidade, a vida privada, a honra e a imagem das pessoas (art. $5^{\circ}, \mathrm{X}$ ) que, de forma genérica, são direitos que compõem o direito à privacidade ${ }^{22}$, aqui entendido como a manifestação da vida íntima, da esfera privada e da personalidade, que o texto constitucional tratou de consagrar (SILVA, 2007).

Decorrem do direito à privacidade as garantias de sigilo previstas no texto constitucional, entre elas os sigilos às comunicações, do domicílio, de dados e profissional. Dispõe o art. 5\%, XII da CRFB que: "É inviolável o sigilo da correspondência e das comunicações telegráficas, de dados e das comunicações telefônicas, salvo, no último caso, por ordem judicial, nas hipóteses e na forma que a lei estabelecer para fins de investigação criminal ou instrução processual penal".

O objeto da proteção constitucional, nesse sentido, é a informação transmitida de um indivíduo a outro por meio de carta, telégrafo, pelo telefone, e que deve ser mantida em segredo entre eles, cuja violação constituirá quebra do sigilo da comunicação (FERNANDES, 2002).

\subsubsection{DA INTERCEPTAÇÃO TELEFÔNICA, TELEMÁTICA, DA GRAVAÇÃO AMBIENTAL E DE IMAGENS}

A interceptação ou monitoramento telefônico e telemático são, dentre as novas tecnologias empregadas na investigação criminal, algumas das mais importantes. Funcionam como técnicas de identificação de possíveis autores de crimes, localização e acompanhamento de pessoas ou coisas, assim como meio de prova por meio da interceptação de dados de voz, texto e sinais.

22 De acordo com Carvalho (2004, p. 52): A privacidade, nos dias de hoje, é posta em risco por grampos telefônicos, microcâmeras poderosas que captam imagens dentro do lar, microgravadores potentes que gravam conversas a grande distância, pela invasão de uma imprensa por vezes sensacionalista e irresponsável, pela circulação de dados individuais fornecidos para um determinado fim e utilizados para outro, pela quebra de sigilos constitucionais, especialmente pelas comissões parlamentares de inquérito, pelas intervenções corporais realizadas pela polícia em suspeitos de prática de infração criminal, enfim uma série de atentados em potencial, somente possíveis em uma sociedade tecnológica e economicamente complexa em que o cidadão, para conviver e para sair do isolamento não mais possível nos XX e XXI, é obrigado a estabelecer relações sociais e econômicas e, assim, expor a público uma parcela ponderável de sua intimidade e de sua família. 
Trata-se de medida de natureza cautelar que, por suas características, deve sempre ser realizada inaudita altera pars, ou seja, sem audiência da parte contrária, sob pena de se inviabilizar a medida.

A Constituição brasileira consignou uma reserva legal qualificada para que a interceptação seja permitida por norma infraconstitucional, isto é, limitou as hipóteses de autorização legal para interceptação telefônica a duas finalidades específicas, a de investigação criminal ou de instrução processual penal. Em ambos os casos, sujeitos à ordem judicial prévia (MENDES et. al., 2010).

No direito brasileiro, a interceptação telefônica é disciplinada pela Lei no 9.296/96, principal documento legal que trata da captação eletrônica da prova. A lei de interceptação telefônica estabeleceu os requisitos para concessão da medida de natureza cautelar probatória. São elas: a) decisão judicial prévia; b) que haja indícios razoáveis de autoria ou participação em infração penal; c) a prova não puder ser feita por outros meios disponíveis; d) o fato constituir infração penal punida com pena de reclusão (crimes de real gravidade).

O primeiro requisito, de natureza formal, consiste na exigência de decisão judicial prévia. A interceptação realizada sem autorização judicial não é válida.

O segundo pressuposto da medida é a exigência de indícios razoáveis de autoria ou participação em infração penal (art. $2^{\circ}$, I), deixando clara a necessidade do fumus comissi delicti para autorização da interceptação. Dessa forma, conclui-se que a interceptação se presta a apurar fato pretérito (já ocorrido) ou em execução (crime permanente), não de fato futuro. Nesse sentido, não é cabível a concessão de medida cautelar de interceptação telefônica para vigiar ou controlar a vida de uma determinada pessoa, ainda que com antecedentes criminais, como meio de prevenir a prática de um crime. Não se admite no direito brasileiro o monitoramento telefônico ou telemático como modalidade de prevenção técnica de delito. Assim, todo pedido de interceptação telefônica deve estar apoiado em investigação criminal previamente formalizada em procedimento investigatório.

O terceiro pressuposto é a inexistência de outros meios de prova disponíveis para a obtenção das informações necessárias. Referido requisito 
merece duas ponderações. De um lado, reconhece a interceptação como um meio de prova, muito embora ele seja mais do que isso, como já ressaltado acima. Por outro, trata-se de critério que guarda relação com o postulado da proporcionalidade, isto é, quando existir outro meio menos gravoso que possibilite se chegar ao autor do crime ou a provas de sua culpabilidade, a opção pela interceptação não é aceitável. Mesmo que a interceptação seja mais adequada (de mais fácil execução comparada a outros meios disponíveis), não concorre em igualdade de condições com os demais meios de prova, sendo uma espécie de meio de prova reserva ou subsidiário.

$\mathrm{O}$ quarto requisito diz respeito à severidade da punição e, correspondentemente à gravidade do delito. A medida somente está autorizada quando, durante a investigação, pelo conjunto de fatos ou circunstâncias documentadas $^{23}$ nos autos, tenha-se como hipótese acusatória a prática de um ou mais crimes apenados com pena de reclusão. Estão excluídas, em regra, fatos hipoteticamente apenados com pena de detenção, prisão simples ou pecuniárias. O STF já entendeu, todavia, que ser "plenamente constitucional a utilização de material de interceptação telefônica para embasar a denúncia dos crimes apenados com pena de reclusão e os crimes que, embora sejam punidos com detenção, sejam conexos àqueles" ${ }^{24}$

Outrossim, cumpre destacar que as interceptações e gravações ambientais - captação de conversas entre presentes em ambiente determinado - estão abarcadas pelo inc. $\mathrm{X}$, do art. $5^{\circ}$ (direito à privacidade) e não pelo inciso XII (interceptação telefônica), de modo que esta não haveria, em tese, que se sujeitar aos limites impostas a estas. Contudo, haja vista cuidar-se de medida de natureza probatória que importa em restrição a direito fundamental, entende-se que a interceptação ou gravação ambiental realizada com o fim de instruir investigação criminal ou processo não pode se eximir dos mesmos limites impostos pela lei de interceptação, quais sejam: a) autorização judicial prévia, tendo em vista a garantia de reserva de jurisdição aplicável a toda iniciativa persecutória que resvale em direitos fundamentais; b) indícios razoáveis de autoria ou participação no delito de certa gravidade (punido com reclusão) - fumus comissi delicti, requisito

23 Como já ressaltado, não se pode admitir interceptação sem o correspondente inquérito policial, como forma jurídica que garante o controle interno e externo da investigação, previamente instaurado, sob pena de termos no lugar de investigação criminal formal, o que comumente se denomina por "grampo", "arapongagem" ou "bisbilhotagem". O que certamente não interessa a um Estado de direito.

24 STF - AI 626.214 AGR - DJ 08.10.2010. 
que deve estar presente em todas as medidas processuais penais de ordem cautelar; c) a prova não puder ser feita por outros meios disponíveis ${ }^{25}$, que enseja um juízo de razoabilidade ${ }^{26}$.

Por esta razão, a lei de crime organizado (Lei no 9.034/95) prevê a captação e a interceptação ambiental de sinais eletrônicos magnéticos, óticos ou acústicos e o seu registro e análise, mediante circunstanciada autorização judicial. Fora dessas hipóteses ela é proibida ${ }^{27}$.

\subsubsection{DO SIGILO DA CORRESPONDÊNCIA}

Quanto ao direito ao sigilo da correspondência, como ressalta Silva (2007, p. 207), “(...) o sigilo da correspondência alberga também o direito de expressão, o direito de comunicação, que é, outrossim, forma de liberdade de expressão do pensamento (...)", sendo que "nele é que se encontra a proteção dos segredos pessoais, que dizem apenas aos correspondentes". O sigilo da correspondência é, portanto, igualmente um corolário do direito à privacidade. Assim, também sujeita sua violação no interesse público à determinação de autoridade judiciária.

Ressalta-se que embora, em princípio, a Constituição tenha aparentemente vedado de forma absoluta a interceptação de correspondências, o fato é que tem se reconhecido que referida garantia não goza de caráter absoluto, - relativização esta extensível também às demais garantias constitucionais —, de modo que, em determinadas situações, mediante a aplicação do princípio da razoabilidade, pode o sigilo epistolar ser afastado em nome

25 Que aqui deve ser entendida como alegação plausível da impossibilidade concreta de emprego de método probatório diverso, menos gravoso. Há que se ter em vista que o método investigatórioprobatório alternativo pode, não raras vezes, causar maior impacto sobre a dignidade do investigado: prisão, busca e apreensão domiciliar etc.

26 Há decisões no sentido de que a gravação feita em local não pode ser tida como prova ilícita (STF: RT 743/550; TJSP: Ap. Crim. 416.537-3/0, São Paulo, 4ª Câm. Crim. Rel. Canellas de Godoy, j. 6.4.204, TJSP: 181/301 apud MOUGENOT, 2009).

27 Cumpre advertir que se tem admitido a possibilidade de exclusão da antijuridicidade da conduta no caso de gravação ambiental clandestina em caso de estado de necessidade ou legítima defesa, tema este que não abordaremos aqui em razão estritos objetivos deste trabalho. Ademais, questão que também atormenta doutrina e jurisprudência diz respeito ao encontro fortuito de provas durante a realização de diligência de interceptação telefônica autorizada. Há posições que sustentam que as provas fortuitas atinentes a outro crime também deveriam ter relação (conexos ou em concurso) com o crime investigado e de responsabilidade do mesmo sujeito passivo. Outros, entretanto, as admitem desde que as provas se refiram a um crime previsto no catálogo de crimes admitidos pela lei (crimes punidos pela lei penal com reclusão) (MENDES et. al, 2010; FERNANDES, 2002). 
do interesse público e de outros valores constitucionais superiores. O sigilo epistolar não pode ser utilizado como subterfúgio para cometimento de crime (NUCCI, 2005) ${ }^{28}$.

Com o argumento de que o sigilo não pode servir como salvaguarda de condutas ilícitas e de que não há liberdades absolutas, tem admitido a violação do sigilo da correspondência em situações excepcionais. Cita-se, como exemplo, acórdão do STF nesse sentido:

A administração penitenciária, com fundamento em razóes de segurança pública, pode, excepcionalmente, proceder à interceptação da correspondência remetida pelos sentenciados, eis que a cláusula da inviolabilidade do sigilo epistolar não pode constituir instrumento de salvaguarda de práticas ilícitas (STF, HC 70.814-5, rel. Min. Celso de Mello, DJU, 24 jun. 1994, p. 16649 apud CAPEZ, 2007, p. 290) 29.

A correspondência, por si só, muitas vezes é a própria materialidade delitiva - corpo de delito - e, portanto, é elemento essencial para caracterização e comprovação do ilícito penal. Observe-se, por exemplo, os casos de extorsão ou de ameaça por meio de cartas.

Pondera-se, todavia, com relação a possibilidade de se quebrar o sigilo epistolar para evitar ou prevenir crime futuro, como, por exemplo, para interceptar o planejamento de um homicídio, um roubo ou sequestro. A interpretação para o referido afastamento de sigilo deveria ser a mesma dada à interceptação telefônica, de modo a ser exigir a existência de indícios razoáveis de autoria ou participação em infração penal, deixando clara a necessidade do fumus comissi delicti para autorização da violação do sigilo da correspondência. Em outras palavras, o sigilo somente pode ser afastado para se apurar fato pretérito (já ocorrido) ou que está acontecendo (crime permanente), não fato futuro.

28 Em sentido diverso, sustenta Aranha (2006, p. 55) que: "A correspondência gráfica, telegráfica ou epistolar, obtida por meio clandestino, isto é, sem autorização e o consentimento de seu emitente, receptor ou titular, jamais poderá servir como meio de prova, pois o art. $5^{\circ}$, XII, da Constituição Federal somente prevê a possibilidade da interceptação telefônica (art. $1^{\circ}$ da Lei 9.296), com o que se pode falar em prova vedada com referência aos outros meios.”

29 Em igual sentido, ver STJ - HC 93874/DF, 5ª Turma, Rel. Min. Arnaldo Esteves Lima, DJE, $2 / 8 / 2010$ 


\subsubsection{Do SIGILO DE DAdOS: BANCÁRIOS, FISCAIS E EM MÍdIAS ELE- TRÔNICAS}

No tocante à inviolabilidade dos dados assinalada no inciso XII, art. 5º o Supremo Tribunal Federal entende que a menção a dados na lei constitucional se refere à comunicação de dados e não aos dados em si, armazenados em computador, por exemplo (MENDES et. al, 2010; CUNHA JÚNIOR, 2008). Assim, não haveria vedação absoluta a obtenção de dados armazenados em mídia eletrônica, estando, contudo, a diligência probatória sob a dependência de ordem judicial, por se tratar de medida que igualmente afeta a dignidade humana e o direito de privacidade.

Cumpre mencionar, ademais, que não obstante a ausência de previsão no texto constitucional da proteção aos sigilos fiscal e bancário prevalece, atualmente, o entendimento de que os referidos sigilos são decorrências do direito de privacidade, protegidos pelo art. $5^{\circ}$, X. Desse modo, gozariam também de status constitucional. Tal entendimento restou acolhido pelo $\mathrm{Su}$ premo Tribunal Federal, restando, portanto, autorizado ao juiz decidir acerca da necessidade do afastamento dos sigilos caso o interesse público pertinente à investigação do ilícito criminal exija (CUNHA JÚNIOR, 2008).

Depreende-se, do que restou dito, que o acesso aos dados sigilosos somente pode ocorrer após o afastamento do sigilo determinado pela autoridade judicial, a requerimento do Ministério Público, representação da autoridade policial ou de ofício pelo juiz, sob pena da prova ser considerada ilícita de forma direta ou mesmo por derivação ${ }^{30}$.

Assim, as perícias contábil-financeiras requisitadas no bojo dos inquéritos policiais, por exemplo, a serem realizadas sobre documentos ban-

30 Ressalta-se que, no sistema brasileiro, os órgãos oficiais de perícia não têm, com toda razão, iniciativa probatória ou capacidade postulatória para requerer documentos objetivando instruir perícias. Referido poder é incompatível com a independência do perito, além de resultar em efetivo prejuízo a atividade probatória, na medida em que poderia se ensejar a criação de um "órgão de investigação paralelo", sobretudo naquelas situações em que os órgãos periciais são autônomos, bem a instituição de um verdadeiro sistema de prova tarifada, na medida em que a perícia teria preponderância sobre as outras espécies de prova, o que não é admitido num sistema de livre convicção motivada como o nosso. Em sistema como o nosso, a (maior) pertinência probatória é definida pragmaticamente, isto é, de acordo com a situação comunicativa. Assim, em um crime de tráfico de entorpecente, a palavra do perito sobre a natureza do material apreendido prevalece diante da confissão do preso, o depoimento das testemunhas, documentos (Suponha-se que, de forma esdrúxula, o material estivesse acompanhado de "nota fiscal" que discriminasse em seu corpo o produto: "quantidade X de cocaína". Ainda assim a comprovação físico-química é essencial). 
cários e fiscais referente a crimes econômicos, fraudes tributárias e outros; as perícias documentoscópicas em cartas que veiculam ameaças ou em outros documentos atinentes às falsificações de toda espécie, entre outras dependem da validade jurídica do corpo de delito. Em outras palavras, se o corpo de delito foi obtido de forma lícita ${ }^{31}$.

\subsection{BUSCAS DOMICILIARES}

Outra questão que interessa particularmente a obtenção ou produção de provas diz respeito à coleta de vestígios e provas em buscas domiciliares, uma vez que não raro os elementos de prova, necessários à investigação, estão protegidos pela restrição de acesso domiciliar ${ }^{32}$.

Consigna o art. 5, XI da Constituição brasileira que "a casa é asilo inviolável do individuo, ninguém nela podendo penetrar sem consentimento do morador, salvo em caso de flagrante delito ou desastre, ou para prestar socorro, ou, durante o dia, por determinação judicial'.

Nos termos já discutidos pelo STF, o conceito do Código Penal é o ponto de partida para a regra constitucional de proteção contra a busca não autorizada. Assim, o conceito de "casa" estende-se:

“(...) a qualquer compartimento privado não aberto ao público, onde alguém exerce profissão ou atividade (CP, art. 150, $\left.54^{\circ}, I I I\right)$, compreende, observada essa especifica limitação espacial (área interna não acessivel ao público), os escritórios profissionais". (HC 82788, relator min. CELSO DE MELLO, Segunda Turma, julgado em 12.4.2005)."

A proteção à habitação familiar ou ao local onde a pessoa exerce sua profissão é expressão do direito a vida privada, a intimidade, assegurada pela

31 Por fim, é importante advertir que o fato de ter a disposição informações sigilosas, mesmo diante de autorização judicial, exige dos agentes públicos zelo necessário sobre seu conteúdo, uma vez que o afastamento circunstancial do sigilo é sempre relativo. Ele está adstrito as necessidades probatórias da investigação e o processo penal e, por esta razão, não pode servir a finalidades estranhas aos estreitos limites da busca da verdade atingível. Desse modo, em caso de divulgação indevida das informações sigilosas contidas em inquérito policial ou processo judicial (conversas telefônicas, extratos de movimentações bancárias, documentos fiscais, cartas entre outros), os responsáveis deverão ser punidos pelo crime de violação de sigilo funcional

32 Não se opõe obstáculo a realização de exames de corpo delito realizados em locais de crime, quando há situações de flagrante delito. É que, nestes casos, a inviolabilidade domiciliar é afastada pela situação flagrancial do delito que o precede. 
Constituição, de modo que somente se admite o ingresso no domicílio de alguém nos casos estritamente autorizados pela norma constitucional e pela lei processual penal.

Sobre a relação da proteção da vida privada com a inviolabilidade do domicílio, SILVA (2007, p. 207), destaca que “(...) a Constituição está reconhecendo que o homem tem direito fundamental a um lugar em que, só ou com sua familia, gozará de uma esfera privada e intima, que terá que ser respeitada como sagrada manifestação da pessoa humana".

As situações em que são permitidas diligências de busca e apreensão estão previstas na lei processual ${ }^{33} \mathrm{e}$ devem ser precedidas de decisões judiciais fundamentadas acerca dos fins e motivos da diligência, como imperativo de uma ordem constitucional garantista ${ }^{34}$. A autoridade solicitante também necessita justificar devidamente seu pedido de busca com base na indispensabilidade, conveniência e oportunidade (TUCCI, 2009).

Assim, em termos de limites procedimentais, a busca e apreensão somente poderá ocorrer quando houver autorização judicial prévia, seja no curso da investigação criminal — instrução provisória lato sensu —, mediante representação da autoridade policial ou a requerimento do Ministério Público, ou de ofício pelo juiz para dirimir ponto relevante ${ }^{35}$. Ou, ainda, duração a instrução definitiva, a requerimento das partes ou de ofício pelo juiz.

Além disso, a diligência de busca e apreensão determinada no mandado deve sempre ter um fim específico, determinado ou determinável pessoa ou objeto, bem como, quando se tratar de coisa (documentos, produtos ou instrumentos do crime etc.), esta deve guardar relação com o fato e as pessoas investigadas, nos termos do art. 243 do CPP. Assim, a busca não deve ser realizada de forma arbitrária e aleatória. Se o que se objetiva encontrar são documentos, armas, drogas, veículos, computadores etc., conforme a natureza do delito, a equipe policial que cumprirá a diligência deverá se restringir a

33 Vide art. 240 e seguintes do CPP.

34 Esclarece-se que restou vedada pela atual Constituição a busca domiciliar realizada diretamente pela autoridade de polícia judiciária, sem autorização judicial, consoante previsão ainda constante da lei processual penal em vigor, construída sob a égide de ordem constitucional distinta.

35 Cf. CPP - Art. 156. A prova da alegação incumbirá a quem a fizer, sendo, porém, facultado ao juiz de ofício: (Redação dada pela Lei no 11.690 , de 2008) II - determinar, no curso da instrução, ou antes de proferir sentença, a realização de diligências para dirimir dúvida sobre ponto relevante. (Incluído pela Lei no 11.690, de 2008). 
procurar e apreender somente os objetos definidos no contexto da necessidade probatória da investigação criminal.

Ressalta-se que a diligência de busca e apreensão domiciliar se tornou uma importante técnica de investigação policial de natureza acautelatória, uma vez que se destina a viabilizar a prisão de criminosos ou a coleta da prova da infração em situações em que os instrumentos ou produtos do crime se encontram protegidos pela inviolabilidade do domicílio ${ }^{36}$.

Desse modo, faz-se necessário atentar para algumas restrições ou condicionamentos impostos à referida diligência.

\subsubsection{A PARTICIPAÇÃo DO PERITO NA BUSCA E APREENSÃo}

Com o desenvolvimento de novos métodos e tecnologias policiais de identificação, coleta e conservação da prova, não raras vezes, é comum o perito criminal oficial acompanhar a diligência de busca e apreensão, como integrante da equipe policial que irá coletar vestígios e provas para a investigação policial, sobretudo quando a coleta demande um conhecimento técnico especializado.

Diante disso, em entendimento manifestado em súmula antiga (Súmula 361 do $S T^{37}$ ), o Supremo Tribunal Federal considerou impedido de elaborar o laudo o que tivesse funcionado, anteriormente, na diligência de apreensão.

Entendemos que o impedimento veiculado pela súmula é salutar tanto em relação ao perito oficial quanto ao não oficial, a fim de não comprometer a imparcialidade do exame técnico. $O$ perito, tanto quanto possível, deve permanecer distante da investigação e limitar-se a realizar o exame técnico nos limites do que lhe foi requisitado no interesse do inquérito ou do processo.

36 A própria lei processual dispõe, todavia, que a diligência de busca também é destinada a descobrir objetos necessários à defesa do réu (art. 241, $\$ 1^{\circ}$, e do CPP). Tal dispositivo revela que a função de polícia judiciária enquanto coadjuvante da prestação jurisdicional, não se presta somente a recolher provas em favor da acusação, mas também da defesa.

37 Súmula 361 do STF: No processo penal, é nulo o exame realizado por um só perito, considerandose impedido o que tiver funcionado, anteriormente, na diligência de apreensão. Embora alguns sustentem que a súmula se refere, sobretudo na primeira parte, a peritos não oficiais, o fato é que a segunda parte da súmula tem maior aplicabilidade prática aos peritos oficiais, uma vez que são estes que acompanham vez por outra as diligências policiais de busca domiciliar. 
Por isso, é necessário sempre distinguir a participação do perito como auxiliar na coleta de vestígios do expert que tem obrigação profissional de declarar no laudo seu testemunho técnico sobre os dados ou eventos sobre os quais foi demandado ${ }^{38}$, sob pena de comprometimento da imparcialidade do perito na realização do exame. Nesse sentido, o cuidado institucional na distinção entre funções exercidas pelo perito durante a investigação tem relevância para garantir tanto a independência técnica do profissional que, não raro, depara-se com essa duplicidade de atribuições no âmbito das instituições policiais (investigador e perito), como também para não possibilitar questionamentos quanto à validade jurídica do exame técnico.

\subsubsection{Do MANDAdo DE BUSCA “Genérico"}

Uma das principais complicações da diligência de busca e apreensão diz respeito a mandados de caráter genérico que, nos termos do art. 243 do $\mathrm{CPP}$, não indicam o mais precisamente possível, a "casa" em que será realizada a diligência e o nome do respectivo proprietário ou morador (I); e/ou não mencionam adequadamente o motivo e os fins da diligência.

Recentemente, o Supremo Tribunal Federal tratou do tema no julgamento do HC 106.566/SP, de relatoria do Ministro Gilmar Mendes. Na decisão do caso, além de reforçar o entendimento de que estabelecimentos comerciais estão protegidos contra o ingresso não consentido e que a busca em referidos recintos deve ser precedida de mandado de busca e apreensão perfeitamente delimitado, a Corte Suprema ainda assentou posição sobre a forma da ordem de busca e conteúdo específico e bem delimitado da diligência.

Segue abaixo um resumo da ação impugnada alvo de decisão pelo STF:

Relatou que foi alvo das investigaçôes policiais federais - "Chacal" e "Satiagraha". Em 27.10.2004, os policiais cumpriram mandado de busca e apreensão, expedido nos autos do PCD 2004.61.81.001452-5 pela 5a Vara Federal Criminal de São Paulo, tendo como alvo o endereço profissional do paciente, localizado na Av. **, **, Rio de Janeiro/RJ, no $28^{\circ}$ andar. Na mesma oportunidade, realizaram busca e apreensão no endereço do Banco

38 Registre-se que o perito, por figurar como órgão auxiliar do sistema de justiça criminal, e a fim de resguardar sua independência técnica, não tem autonomia para realizar perícia, ou seja, não age por iniciativa própria, mas tão-somente quando provocado (requisição). 
**, localizado no $3^{\circ}$ andar do mesmo edificio, sem que houvesse mandado judicial para tal endereço.

No caso em exame, entendeu a $2^{\text {a }}$ Turma do STF que a diligência de busca foi indevidamente estendida para endereço ulterior sem nova autorização judicial, no que considerou ilícito o resultado da diligência e concedeu ordem para determinar a inutilização das provas.

Dois detalhes importantes devem ser considerados a partir das razões de decisão formuladas $2^{\mathrm{a}}$ Turma do STF. O primeiro é que os fundamentos da decisão se concentram, principalmente, na delimitação espacial e pessoal do mandado. Como a ordem foi dirigida ao endereço profissional do paciente, situado no $28^{\circ}$ andar de determinado edifício, bem como que se dirigia à pessoa física do paciente e não a instituição financeira, não era viável estender os limites do mandado para se realizar uma busca no endereço da pessoa jurídica, situado no $3^{\circ}$ andar do mesmo edifício, ainda que verificada suspeita de ligação entre os atores investigados.

O segundo ponto interessante é que diante da necessidade de realizar busca em outro endereço - em sala da instituição bancária no $3^{\circ}$ andar - e cientes dos limites do mandado e de que sua extrapolação poderia invalidar eventuais provas coletadas, os executores entraram em contato com o juiz federal responsável pela vara judicial que expediu os mandados e solicitaram uma nova ordem de busca e apreensão dos servidores de informática do banco. O magistrado em questão, por meio de ofício, não autorizou a apreensão dos servidores, mas apenas o espelhamento dos mesmos em outros dispositivos de mídia. Contudo, entendeu a $2^{\mathrm{a}}$ Turma que o ofício não era documento idôneo para autorizar a busca e apreensão (espelhamento) dos servidores do banco, uma vez que o documento em questão não poderia ser considerado um mandado de busca e apreensão, nem a ele equivalente.

A impugnação da forma pela $2^{a}$ Turma da Suprema Corte ${ }^{39}$, que não equiparou o ofício do juízo competente, - ressalta-se, em que este especificou o objeto, local e pessoa que deveria ser submetida à busca - deve ser vista como um alerta para necessidade de observação rigorosa dos requisitos legais, não apenas no que diz respeito ao conteúdo do mandado (local, pessoa, fins e motivos da ordem), mas também à forma jurídica.

39 Particularmente, entende-se que a ordem judicial deve especificar a pessoa, o local da busca e os objetos a serem apreendidos. Contudo, a forma escrita por meio da qual a ordem é emanada e instrumentalizada não deveria tão rigorosa. Não é incomum que juízes aproveitem as decisões como mandados de busca e apreensão ou que referidos mandamentos assumam a forma de ofícios. 


\subsection{A COleta de VeStígios E PROVAS EM SITUAÇÕes DE FLA- GRANTE DELITO}

Decorre da norma constitucional que a situação de flagrância da prática de um delito, excepciona a regra de vedação à violação domiciliar (art. $5^{\circ}$, XI CF/88). Sendo assim, em situação de flagrância a polícia pode adentrar o domicílio sem consentimento para, em primeiro lugar, fazer cessar o delito em curso ou prender seus possíveis autores. E, em segundo lugar, coletar vestígios e provas que demonstrem a veracidade do fato.

Em síntese, a situação de flagrância propicia a oportunidade para a busca, coleta e/ou apreensão de todas as provas que servirem para o esclarecimento do fato e suas circunstâncias (art. 6º III do CPP), sem a necessidade de prévia autorização judicial.

No caso mencionado, há uma relação direta entre o fato contido pela intervenção policial e os materiais ou instrumentos do delito arrecadados que servem, estritamente, para reconstruir a constatação do fato em juízo. Contudo, não raro, nesse caso, a polícia pode se deparar, fortuitamente, com outros elementos ou provas pertinentes a outros crimes que não necessariamente guardem direta vinculação com aquele que motivou a intervenção ou com investigado. Referida situação, conhecida como encontro fortuito de provas, será melhor analisada no item 3.4 a seguir.

\subsection{DO ENCONTRO FORTUITO DE PROVAS}

O tratamento dado ao encontro fortuito de provas pela doutrina e jurisprudência é variado. Embora já tenha sido admitida pela jurisprudência do $\mathrm{STF}^{40}$, o fato é que seus contornos de admissibilidade não são claros, sobretudo quando os objetos encontrados não são objeto de crime permanente ou que não tenham conexão com o fato apurado.

Há aqueles que sustentam que se trata de uma hipótese de prova ilícita, uma vez que a prova é encontrada sob o permissivo judicial de busca de prova relacionada ao outro fato investigado. Haveria, assim, um excesso de

$40 \mathrm{O}$ encontro fortuito de provas foi admitido pela jurisprudência do STF. Vide HC 84224/DF, rel. Min. Gilmar Mendes, 13.12.2005; AI-AgR 626214, rel. Min. Joaquim Barbosa, 21.09.2010. Nesse último julgado, embora se exija a conexão entre os delitos, admite-se que o crime descoberto, conexo ao que foi objeto de interceptação, seja punido com detenção. 
mandado que afrontaria os direitos fundamentais do investigado, na medida em que a diligência deve se dirigir a busca de objetivo específico ${ }^{41}$. Por outro lado, há entendimento diverso no sentido de que referida prova encontrada fortuitamente pode ser admitida, seja em diligência de busca e apreensão ou interceptação telefônica, desde que respaldada por autorização judicial e se trate de infração conexa ou em concurso ${ }^{42}$, bem com que o potencial delito possa ser imputado ao mesmo sujeito investigado ${ }^{43}$.

Gomes e Cervini (apud Fernandes, 2002) defendem que caso se trate de ausência de conexão ou de prova relacionada a outra pessoa, embora nula a prova, esta pode servir como notitia criminis, ou seja, como fonte de prova para se dar início à outra investigação ${ }^{44}$. Com relação à interceptação telefônica, o entendimento esposado pelos autores é aceitável. Em termos práticos, a notícia ou menção de prática ou participação em outros delitos não apenas pode, como deve servir de indício suficiente para abertura de novo procedimento investigatório. Porém, como haverá, nos mais das vezes, uma necessidade de aprofundar as investigações, com o redirecionamento dos esforços de investigação sobre outras pessoas ou coisas, ou seja, uma alteração do objeto originalmente investigado, entende-se que a mudança de perspectiva investigativa exigirá uma nova ordem judicial autorizando o monitoramento telefônico para apuração do fato novo descoberto, desde que preenchidos os requisitos de imprescindibilidade da medida.

Há que se destacar, ainda, o encontro fortuito de notícia relacionada à prática de ilícito futuro. Nesse caso, não há que se cogitar a necessidade de conexão entre o fato investigado e o descoberto, uma vez que ponderação sobre a conexão se refere apenas a fatos pretéritos ${ }^{45}$. A descoberta de notícia sobre conduta delituosa futura, por meio de interceptação telefônica destinada a apurar fato diverso do encontrado, deve ser objeto de ação

41 É a posição de Oliveira (2008) aplicável a busca. Igual posição adota Aranha (2006) em relação a interceptação.

42 A conexão pode ser tanto intersubjetiva como instrumental decorrente de encontro fortuito de prova.

43 É a posição defendida por Fernandes (2002) tanto em relação à interceptação quanto a busca. No sentido de admiti-la em face da interceptação: Gomes e Greco Filho (apud Fernandes, 2002). Também no sentido de haver compatibilidade do uso de prova obtida fortuitamente através de interceptação telefônica licitamente conduzida, ainda que o crime descoberto, conexo ao que foi objeto da interceptação, seja punido com detenção com o art. 5, XII e LVI, ver AI 626.214 AgR/MG, Rel. Min. Joaquim Barbosa, DJe 08-10-2010.

44 Para uma análise das situações autorizadas no direito estrangeiro, ver Fragoso (1993).

45 Nesse sentido, ver decisão da Quinta Turma do STJ no HC 200602419935, rel. Min. Felix Fischer, publicada em 14.05.2007. 
inibitória ou preventiva, independentemente de sua conexão com o fato investigado, uma vez que o Estado não pode se omitir diante do conhecimento da preparação do ato.

De outra parte, a restrição anteriormente exposta não se aplica à busca e apreensão. A especificidade do objeto e sua conexão com o delito que comprova não pode ser desprezada. Digamos, por exemplo, que durante a execução de um mandado de busca e apreensão de entorpecentes sejam encontrados na residência do investigado diversos cartões "clonados" que foram utilizados para compras e saques no comércio local. Neste caso, como admitir a invalidade da prova (materialidade delitiva) encontrada fortuitamente? Qual o direito fundamental do investigado violado nesse caso? Se já houve afastamento da proteção domiciliar não há que se falar em ilicitude da prova obtida fortuitamente.

O sistema de justiça criminal não pode simplesmente ignorar a existência de vestígios ou provas de outro ilícito em situações de encontro fortuito, devendo o material apreendido dar ensejo à instauração de procedimento investigatório próprio. Nesse sentido, já entendeu o Superior Tribunal de Justiça a respeito de uma apreensão de arma de fogo de uso permitido, cuja guarda se verificou irregular, encontrada fortuitamente durante o cumprimento de um mandado de busca e apreensão:

A apreensão decorrente do conhecimento fortuito da posse ilegal/irregular das armas e muniçôes não implica extrapolação ou nulidade do mandado expedido para a busca e apreensão de objetos referentes a crime diverso. $O$ mandado foi adequadamente expedido, mas a apreensäo decorreu do flagrante constatado no interior da residência do acusado (APn 686/AP - AÇÃO PENAL 2011/0238199-0/ REL. MIN. João Otávio de Noronha, DJe 05/03/2014).

\subsection{A NÃO CONVALIDAÇÃO DAS PROVAS OBTIDAS ILICITAMENTE}

Consoante acentuado, a busca e apreensão é um importante instrumento a serviço da investigação criminal, uma vez que possibilita o acesso a vestígios e provas como drogas, mídias, documentos e armas armazenados em local acobertado pela inviolabilidade do domicílio.

Ocorre que, uma vez violado o condicionamento material ao meio de obtenção de prova — proteção da intimidade do domicílio —, eventuais 
diligências sustentadas ou requeridas a partir de objetos apreendidos ilicitamente, deverão ser rejeitadas pelo judiciário ou tida como inválidas. É o caso, por exemplo, da representação pela prisão preventiva sustentada em documentos falsos apreendidos em diligência ilegalmente realizada. Ou, ainda, o exame pericial realizado em documento obtido ilicitamente. A validade técnica do exame não tem o condão de afastar eventual invalidade jurídica do objeto examinado, tornando, portanto, inútil o testemunho pericial.

É que a validade do argumento técnico-dedutivo - compatibilidade do material genético de vítima de homicídio com o material coletado nas roupas do suspeito A - não tem o condão de assegurar a verdade aceitável da conclusão a respeito da materialidade ou autoria. Embora válido o argumento técnico (exame de DNA), se uma das premissas (o material fora recolhido licitamente no imóvel do suspeito) for falsa, a conclusão sobre o fato não pode ser verdadeira, no sentido de ser admitida como prova para sua condenação. A validade da conclusão de um argumento está condicionada a existência de premissas admitidamente verdadeiras, no caso, da observância dos limites à obtenção da prova.

Decisão importante sobre o tema foi proferida pelo TRF da $1^{\text {a }}$ Região ${ }^{46}$ segundo o qual:

PROCESSUAL PENAL. HABEAS CORPUS. BUSCA E APREENSÃO JULGADA ILEGAL. MATERIAL APREENDIDO. INSERVIBILIDADE JURIDICA. ABERTURA DE INQUÉRITO POLICIAL COM BASE NO MATERIAL APREENDIDO: IMPOSSIBILIDADE.

1. Tendo o Tribunal, ao julgar habeas corpus, considerado ilegal as escutas telefônicas empreendidas nos terminais do paciente, e determinado a devolução do material gravado, considerando, outrossim, contaminada pela ilegalidade a busca e apreensão determinada com base nas escutas, a abertura de inquérito policial para seqüenciar investigaçôes, com lastro no material ilegalmente apreendido, constitui coação ilegal.

2. A prova obtida ilegalmente, ou em procedimento nulo - no caso, em decorrência de uma busca e apreensão contaminada pela ilegalidade da escuta que lhe dera base -, constitui um nada jurídico, não podendo, por via de conseqüência, ser admitida nos autos do processo, ou servir de base para a deflagração de investigação policial,sem

46 HC 11173 MT (2004.01.00.011173-4), Relator(a): Desembargador Federal Olindo Menezes Julgamento:18/05/2004 - Órgão Julgador: Terceira Turma - Publicação: 04/06/2004, DJ p.30. 
prejuizo de poder a instância pré-processual de combate ao crime agir com base em outros elementos idôneos, se deles dispuser.

3. Concessão do habeas corpus. Trancamento da ação penal.

Depreende-se da decisão que o mandado judicial de busca e apreensão concedido a partir de informação obtida em escuta telefônica ilegal contamina a prova gerada por aquela diligência, tornando-a não prova ou prova inexistente em razão de sua ilicitude (ARANHA, 2006).

\section{O Privilégio da Não Autoincriminação e as INTERVENÇÕES CORPORAIS}

Cabe ainda mencionar a restrição à obtenção de vestígios e provas por meio das chamadas intervenções corporais. Por se tratarem de ações que podem contrariar o direito de autodefesa negativa, isto é, o privilégio contra a não autoincriminação ${ }^{47}$, consubstanciado no regular exercício de não fazer prova contra si mesmo, bem como o princípio da inocência e a dignidade humana, as intervenções corporais têm importância singular para a investigação criminal (SAAD, 2004; LOPES JUNIOR, 2010).

O privilégio contra autoincriminação tem sua origem vinculada ao direito de defesa, ou melhor, à ausência dele, muito mais que ao direito ao silêncio.

Ao contrário que se apregoa rotineiramente, até o século XVIII o procedimento criminal da tradição do Common Law e o procedimento europeu continental moderno apresentavam amplas similitudes. $\mathrm{O}$ direito inglês desse período foi marcado por fortes características inquisitoriais no julgamento dos casos criminais ordinários - motivado, sobretudo pelo grande número de conflitos a serem resolvidos pelo sistema de justiça pública —, que resultaram, na prática, no confisco da ação do acusador privado. Entre as razões para isso podemos destacar: a) a ausência de acusadores públicos e defensores designados para defesa do acusado; b) o papel preponderante do juiz na instrução da causa e a influência exercida por sobre a convicção dos jurados; c) o papel de investigar os crimes, selecionar e ouvir as testemunhas previamente ao julgamento (pretrial),

47 Além de derivar da garantia do silêncio e direito ampla defesa e contraditório como corolários de um devido processo legal, o princípio que veda a obrigatoriedade de autoincriminação está previsto explicitamente no artigo. 
bem como assessorar a vítima ou seus parentes no processamento do autor era do Juiz de Paz (LAGBEIN, 1994) ${ }^{48}$.

Não obstante a ausência de uma forma "adversarial" de processo, em que as participam ativamente da produção da prova em um procedimento oral, pudesse contribuir para a celeridade dos julgamentos, consoante assevera Lagbein (1994), a ausência de advogado de defesa tinha como consequência o dever do acusado falar em sua própria defesa ${ }^{49}$. Nesse tipo de processo, portanto, não era possível distinguir claramente o papel do acusado como testemunha ou autor do fato. Essa confusão de papéis atribuía ao investigado/acusado a condição de testemunha qualificada sobre o fato do qual deveria se defender. Com isso, não havia necessidade de assistência de um defensor, uma vez que, se fosse inocente, sua defesa seria tão efetiva quanto a de qualquer advogado; e, se fosse culpado, somente falando por si mesmo ele seria capaz de dizer exatamente o que teria ocorrido, o que dificilmente ocorreria caso os fatos fossem revelados por interposta pessoa (TEDESCO, 2004; LAGBEIN, 1994).

Apenas com apropriação paulatina do processo pelos advogados, tanto na acusação como na defesa, a parte acusada passou a não precisar mais falar por si própria ${ }^{50}$. Em outros termos, o advento de um modelo processual de partes representadas possibilitou ao acusado o direito ao silêncio e, por conseguinte, a não ter que produzir prova contra si mesmo (LAGBEIN, $1994)^{51}$.

A participação dos defensores refletiu, por um lado, na desoneração da parte em colaborar com o juízo em seu desfavor e, como consequência obrigou o acusador a buscar provas que não (somente) a declaração/confis-

48 Além de derivar da garantia do silêncio e direito ampla defesa e contraditório como corolários de um devido processo legal, o princípio que veda a obrigatoriedade de autoincriminação está previsto explicitamente no artigo $8^{\circ}, n^{\circ}$ 2, letra $g$ da Convenção Americana de Direitos Humanos, incorporada ao ordenamento jurídico brasileiro.

49 Destaca Lagbein (1994) outros fatores que interferiam na obrigação do acusado de falar em sua própria defesa: a) a ideia de que o tribunal atuava também favor do réu; b) a proibição de apresentação de testemunhas de defesa; c) a prisão provisória que dificultava a localização de eventuais testemunhas entre outros.

50 No início da participação dos defensores no processo, o acusado ainda deveria falar por si mesmo, como argumenta Stephen (apud Tedesco, 2004, p.51). Em igual sentido, Lagbein (1994) diz que o advogado foi proibido de se dirigir ao júri até o século XIX.

51 Ressalta-se, ademais, que essa evolução no direito à defesa e, por conseguinte, ao silêncio, está diretamente relacionada à consagração do princípio da inocência no século XVIII. 
são do acusado. O privilégio da não autoincriminação, portanto, além de ser reconhecido como um direito humano de proteção da liberdade e dignidade humana - e não apenas uma regra de prova - também tem o objetivo de assegurar o caráter acusatório e contraditório do processo ao encarregar ao acusador do ônus de provar a culpa e a possibilidade do imputado contradizer a hipótese acusatória. Em síntese, o direito de não autoincriminação implica no reforço do princípio da presunção de inocência e tem como consectários o direito ao silêncio e o direito à defesa e contraditório que sustentam um devido processo legal. A leitura das intervenções corporais deve ser feita, portanto, à luz dessas prerrogativas defensivas do investigado/acusado no processo penal.

\section{I DAS INTERVENÇÕES CORPORAIS NO DIREITO BRASILEIRO}

Consoante cita Carvalho (2004, p. 67), são exemplos comuns de intervenções corporais:

(...) a extração de sangue para a realização de exame de pareamento cromossômico (DNA) ou de dosagem alcoólica, a exalação de ar também para verificação do nivel de álcool no organismo, a coleta de urina, a extração de substâncias contidas debaixo das unhas dos suspeitos (finger scrapings), cirurgias no próprio corpo da pessoa suspeita, coleta de impressóes digitais, a gravação de conversa entre duas pessoas (gravação ambiental), o exame em cavidade do corpo (ânus, vagina), a coleta de lixo doméstico para a investigação etc. que remontam ao direito à intimidade 52 .

Cumpre observar que a identificação criminal e a busca pessoal são, de fato, as duas formas de intervenções corporais mais comumente toleradas pelo nosso direito.

No tocante a identificação criminal, por força de permissivo constitucional, ela é autorizada desde que o investigado não possua identificação civil ou nos casos autorizados pela lei (art. $5^{\circ}$, LVIII, CF/88). O artigo $3^{\circ}$, IV da Lei no 12.037/2009, que dispõe sobre a identificação criminal, por sua vez, prevê que, não obstante apresentado documento de identificação, poderá ocorrer identificação criminal quando "a identificação criminal for

$52 \mathrm{O}$ direito brasileiro autoriza as hipóteses de gravação de conversa entre duas pessoas (gravação ambiental) e a coleta de lixo doméstico para investigação, desde que devidamente autorizadas por um juiz, muito embora entendamos que seu enquadramento como intervenção corporal não seja apropriado. 
essencial às investigaçóes policiais, segundo despacho da autoridade judiciária competente, que decidirá de ofício ou mediante representação da autoridade policial, do Ministério Público ou da defesa".

A função da identificação criminal, sob a perspectiva da individualização do sujeito investigado, busca alcançar dois objetivos: a) evitar os equívocos na responsabilização criminal; b) selecionar o investigado. Assim, em primeiro lugar, objetiva prevenir uma falsa ou equivocada responsabilização. Em segundo lugar, funciona como uma indicação ou atribuição provisória de culpabilidade, no âmbito da investigação criminal ${ }^{53}$.

A identificação criminal também é um instrumento de produção do conhecimento por parte dos órgãos policiais de investigação, na medida em que possibilita às organizações conhecer e chegar mais facilmente potenciais criminosos seja o próprio identificado, em caso de reincidência, ou alguém que componha sua rede de contatos. A identificação, portanto, serve para direcionar os órgãos policiais a um universo mais restrito de suspeitos, ainda que num primeiro momento.

A identificação criminal se presta, ainda, à finalidade probatória. É possível, a partir do confronto entre impressões colhidas no local de crime e os registros em bancos de dados ou material datiloscópico colhido de um suspeito, concluir-se, ao menos de forma indiciária, pela autoria de um crime.

A técnica de identificação criminal, em regra, utiliza-se da coleta de impressões dactiloscópicas, como método simples e adequado para identificar - individualizar - o investigado, bem como para confrontar evidências encontradas no local do crime com as do suspeito. Ocorre que com o advento da Lei no $12.654 / 2012^{54}$, abriu-se o caminho para identificação criminal genética. Diante da autorização constitucional e legal e, em face do privilégio da não autoincriminação, é possível ao investigado se recusar a se submeter à identificação criminal?

53 A identificação criminal está diretamente atrelada ao procedimento de indiciamento policial em que autoridade policial, por meio de um ato fundamentado, a partir da análise técnico-jurídica do fato, indica um suposto autor, a materialidade do crime e suas circunstâncias. Do ponto de vista do indiciado, a formalização do indiciamento impõe-lhe o ônus de ter que impugnar indícios e provas que pesam sobre ele.

54 Com a edição da Lei n ${ }^{\circ}$ 12.654, de 28 de maio de 2012, que prevê a coleta de material genético como forma de identificação criminal, restou autorizada a utilização do perfil genético como forma de identificação criminal. 
A resposta à pergunta não é fácil, sobretudo em virtude do reconhecimento jurisprudencial de proibições de intervenções corporais igualmente lesivas do direito de produzir prova contra si mesmo como, por exemplo, o de obrigar alguém a se submeter ao teste do bafômetro (alcoolemia) para fins de responsabilização criminal em delitos de trânsito ou a exame de DNA em demandas civis de investigação de paternidade ${ }^{55}$. Assim, em termos práticos, o que justificaria tratamento distinto no que diz respeito à identificação criminal?

Como elemento auxiliar nas investigações criminais, a identificação criminal do civilmente identificado está condicionada a sua essencialidade para as apurações policiais. Assim, em que pese o eventual caráter negativo defensivo da identificação, - no sentido de que a defesa pode pleitear a identificação do investigado no sentido corroborar a tese defensiva de negatividade de autoria - a prática, todavia, demonstra que a identificação tem, primordialmente, o objetivo demonstrativo de culpabilidade. $\mathrm{O}$ valor a ser alcançado, portanto, é o de defesa do Estado por meio da viabilização da persecução criminal tendo como consequência uma restrição da autodefesa negativa pelo investigado, consistente na impossibilidade de resistir à pretensão estatal de sujeitá-lo produzir prova contra ele mesmo.

Desse modo, observa-se que há dois valores em conflito: o valor segurança - aqui entendida não apenas segurança pública, mas também de segurança jurídica no sentido de respeitabilidade de regras - e o valor de dignidade representado pelos princípios da presunção de inocência, ampla defesa e direito ao silêncio que consubstanciam o privilégio da não autoincriminação.

Como mencionado, a racionalidade jurídica depende em alguma medida da coerência entre as normas. Coerência esta que se sustenta não apenas enquanto livre de contradição lógica entre normas, mas como acordo em torno de propósitos comuns. A coerência, assim, exige uma "compatibilidade axiológica" entre uma ou mais regras jurídicas, justificáveis em termos de princípios ou valores comuns (MACCORMICK, 2009). Entretanto, ainda que o Direito expresse e busque realizar uma pluralidade de valores, há que se admitir que esses valores são precariamente hierquizáveis. Por isso, a dificul-

55 Mesmo que, nesse caso, por se tratar de processo civil, admita-se a inversão do ônus da prova pela presunção, nos termos da sumula 301, que assim dispõe: "Em ação investigatória, a recusa do suposto pai a submeter-se ao exame de DNA induz presunção juris tantum de paternidade". 
dade de se justificar e admitir prioridades e níveis diferentes entre princípios e valores, enquanto possíveis derivações de princípios gerais nos leva a justificar a referida compatibilidade de valores em termos de razão prática, ou seja, mensurar os valores em cada situação (MACCORMICK, 2009).

Uma forma de tentar compatibilizar os valores em jogo sem recorrer a ponderações ${ }^{56}$ é sujeitar a coleta de material para a identificação, em situações de não colaboração do investigado, às diretrizes de minima invasividade ou de cooperação passiva. Assim, a fim de não constranger o investigado a produzir prova contra si mesmo as medidas de identificação não podem ser invasivas (extração de sangue, p.ex.) ou exigirem colaboração ativa do investigado. Esse é sentido da referida proteção jurídica como vimos acima. Todavia, produzir prova contra si não é o mesmo que tolerar que se produza a partir inspeções corporais (como, por exemplo, exames de raios-X para detectar a ingestão de capsulas contendo substâncias entorpecentes $)^{57}$ ou coleta de fluidos ou tecidos corporais (saliva, pele etc.) que não importem em sujeitar o investigado a participação ativa na coleta do material. A identificação datiloscópica é, assim, um bom exemplo de processo de identificação que não exige a participação ativa do investigado.

Ademais, ressalta-se que a própria Lei de Identificação Criminal, com a nova redação dada pela Lei $\mathrm{n}^{\circ} 12.654 / 2012$, dispõe que coleta do material para realização do perfil genético deverá ser feita por técnica "adequada e indolor". A adequação, contudo, a partir de uma leitura mais garantista, não pode ser vista apenas sob o ponto de técnico, mas como meio que não exija uma colaboração ativa do investigado. A adequabilidade da forma de coletar o material está em não constranger o investigado, sobretudo pela utilização de técnicas invasivas.

Por outro lado, a segunda forma de intervenção corporal autorizada pelo direito brasileiro é a busca pessoal, que tem por finalidade tanto a prevenção como investigação de crimes. A busca pessoal é comumente criticada enquanto medida com fins preventivos (garantia de segurança pública), uma vez que as abordagens aleatórias têm pouca efetividade na descoberta ou prevenção do crime, além de seu forte caráter seletivo em detrimento dos mais vulneráveis (LEA; YOUNG, 2008). No que diz respeito à investigação, a busca corporal tem por objetivo identificar provas ou possíveis instrumentos

56 Ver por todos: Alexy (2008).

57 Rcl 2.040 QO, Relator (a): Min. NÉRI DA SILVEIRA, Tribunal Pleno, julgado em 21/02/2002, DJ 27-06-2003, pp-31. 
ou produtos de crime trazidos junto ao corpo ${ }^{58}$. Por isso, trata-se de diligência que deve ser executada somente quando haja suspeita fundada sobre a pessoa que ser objeto da revista pessoal e, com o cuidado necessário para evitar o constrangimento excessivo que pode decorrer da ação policial ${ }^{59}$.

Há que se ponderar, portanto, na situação concreta, sob a perspectiva da proporcionalidade, se a medida é de fato necessária, adequada e se dentre a medidas possíveis de serem utilizadas, ela é a que menor prejuízo ofertará ao cidadão.

Ressalta-se que a coleta de material na superfície do corpo humano, como nas cavidades humanas e nas unhas, equipara-se à busca pessoal e como tal devem receber o mesmo tratamento destinado a estas, ou seja, a de serem admitidas quando necessárias (CARVALHO, 2004).

Também devem ser admitidos os exames clínicos quando necessários (constatação do estado de embriaguez), desde que o investigado não seja forçado a participar ativamente, muito embora haja uma dificuldade prática em se distinguir a colaboração ativa e passiva (SAAD, 2004) ${ }^{60}$.

Em resumo, não são toleráveis em nosso direito a extração de sangue para a realização de exame de pareamento cromossômico (DNA) ou de dosagem alcoólica ${ }^{61}$, a exalação de ar também para verificação do nível de

58 Cf. Art. 240 do CPP.

59 Embora a lei processual determine que a busca pessoal deva precedida da expedição de mandado, sempre que a própria autoridade policial ou judiciária não a realizar pessoalmente (art. 241 do CPP: "Quando a própria autoridade policial ou judiciária não a realizar pessoalmente, a busca domiciliar deverá ser precedida da expedição de mandado), bem como que deverá o mandado indicar, o mais precisamente possível, o nome da pessoa que terá de sofrê-la ou os sinais que a identifiquem e o motivo da diligência, na prática tal providência não ocorre. A razão por que isso acontece é que o próprio $\mathrm{CPP}$ prevê situações em que é dispensável o mandado (Art. 244 do CPP: "A busca pessoal independerá de mandado, no caso de prisão ou quando houver fundada suspeita de que a pessoa esteja na posse de arma proibida ou de objetos ou papéis que constituam corpo de delito, ou quando a medida for determinada no curso de busca domiciliar"). Ocorre que as hipóteses de dispensa de mandado previstas na lei praticamente abrangem todas as possíveis situações no curso da investigação ou da ação policial preventiva que poderiam demandar a expedição de um mandado.

60 Em face desta dificuldade em se diferenciar a colaboração passiva e ativa, entende Saad (2004) que a simples aplicação do princípio nemo tenetur se detegere não resolve o problema definitivamente, haja vista as diversas situações em que se exige a participação passiva ou mesmo ativa do investigado em claro prejuízo a sua pessoa: reconhecimento (art. $6^{\circ} \mathrm{c} / \mathrm{c}$ art. 226 a 228 do CPP), acareação (art. $6^{\circ} \mathrm{c} / \mathrm{c}$ art. 229 e 230 do CPP), reprodução simulada dos fatos ou reconstituição (art. $7^{\circ}$ do CPP), a fornecer material para exame (DNA, material gráfico, sangue), sendo que nestes casos, a resistência ou desobediência em cooperar não pode ser punida.

61 Em recente decisão, a $6^{a}$ Turma do Superior Tribunal de Justiça, disponível no Informativo 438 
álcool no organismo, a coleta de urina, cirurgias no próprio corpo da pessoa suspeita, o fornecimento obrigatório de material gráfico para realização de exame grafotécnico, a participação em reprodução simulada dos fatos, todos eles em razão do intransponível óbice posto pelos princípios da dignidade da pessoa humana, da intimidade, da proibição de obrigatoriedade de que a pessoa produza prova contra si mesmo (privilégio de não autoincriminação) e da presunção de inocência ${ }^{62}$.

Mesmo em casos de crimes graves, não há que se admitir o uso de critérios hermenêuticos — razoabilidade - que afastem a referida proteção constitucional $^{63}$ nas situações relacionadas acima, uma vez que está em jogo a

do STJ, sobre o tema Embriaguez ao volante. Exame. Alcoolemia, assim se pronunciou: "Antes da reforma promovida pela Lei n. 11.705/2008, o art. 306 do CTB não especificava qualquer gradação de alcoolemia necessária à configuração do delito de embriaguez ao volante, mas exigia que houvesse a condução anormal do veículo ou a exposição a dano potencial. Assim, a prova poderia ser produzida pela conjugação da intensidade da embriaguez (se visualmente perceptível ou não) com a condução destoante do veículo. Dessarte, era possível proceder-se ao exame de corpo de delito indireto ou supletivo ou, ainda, à prova testemunhal quando impossibilitado o exame direto. Contudo, a Lei n. 11.705/2008, ao dar nova redação ao citado artigo do CTB, inovou quando, além de excluir a necessidade de exposição a dano potencial, determinou a quantidade mínima de álcool no sangue (seis decigramas por litro de sangue) para configurar o delito, o que se tornou componente fundamental da figura típica, uma elementar objetiva do tipo penal. Com isso, acabou por especificar, também, o meio de prova admissível, pois não se poderia mais presumir a alcoolemia. Veio a lume, então, o Dec. n. 6.488/2008, que especificou as duas maneiras de comprovação: o exame de sangue e o teste mediante etilômetro ("bafômetro"). Conclui-se, então, que a falta dessa comprovação pelos indicados meios técnicos impossibilita precisar a dosagem de álcool no sangue, o que inviabiliza a necessária adequação típica e a própria persecução penal. É tormentoso ao juiz deparar-se com essa falha legislativa, mas ele deve sujeitar-se à lei, quanto mais na seara penal, regida, sobretudo, pela estrita legalidade e tipicidade. Anote-se que nosso sistema repudia a imposição de o indivíduo produzir prova contra si mesmo (autoincriminar-se), daí não haver, também, a obrigação de submissão ao exame de sangue e ao teste do "bafômetro". Com esse entendimento, a Turma concedeu a ordem de habeas corpus para trancar a ação penal. Precedente citado do STF: HC 100.472-DF, DJe 10/9/2009. HC 166.377-SP, Rel. Min. Og Fernandes, julgado em 10/6/2010."

62 Chouk (2006, p. 101) cita como exemplos decisões do STF nesse sentido em que se "permite ao paciente o exercício do direito de silêncio, não estando, por essa razão, obrigado a fornecer os padrões vocais necessários a subsidiar prova pericial que entende lhe ser desfavorável (HC 83.096, Rel. Min. Ellen Gracie, DJ 12/12/03)" ou, ainda, de que "há de ser interpretado no sentido de não poder ser o indiciado compelido a fornecer padrões gráficos do próprio punho, para os exames periciais, cabendo apenas ser intimado para fazê-lo a seu alvedrio (HC 77.135, Rel. Min. Ilmar Galvão, DJ 06/11/98)”.

63 É a posição de Lopes Júnior (2003). Ressalta-se, todavia, que argumenta parte da doutrina que "atendendo ao bom senso, devemos buscar um ponto de equilíbrio, estabelecendo um critério que atenda à razoabilidade (ponderação e proporcionalidade de bens e valores) para solucionar o conflito que se estabelece. Partindo dessa linha de raciocínio, devem ser toleradas as intervenções corporais que não representam nenhum risco para o sujeito passivo e que tampouco possam ser qualificadas de humilhantes, quando delito seja grave e não exista outra forma de comprovar a autoria (ou algum outro pressuposto de responsabilidade)." (LOPES JUNIOR, 2003, p. 350/351). Acrescem-se, ainda, como requisitos: a) a existência de norma processual prévia que a autorize; b) o imputado deve estar determinado; c) o resultado não pode ser considerado prova absoluta, como a confissão; d) deve ser 
liberdade pessoal e a violação ao direito a não autoincriminação (LOPES JUNIOR, 2010). Desse modo, a recusa em colaborar constitui exercício regular de um direito e não pode o investigado se coagido ou punido em face dela.

Outra forma de tentar superar a clara dificuldade em obter o material necessário à definição ou exclusão da autoria do delito, sem condicioná-la a obrigatória colaboração do investigado, consiste na arrecadação de material genético (sangue, saliva, urina, cabelo, sêmen etc.) que estão depositados em recipientes ou materiais fora do corpo (roupas, escovas de cabelo). O mesmo se aplica ao lixo doméstico e ao material gráfico.

Quanto ao primeiro pressupõe-se o abandono da coisa ou renúncia ao sigilo sobre o conteúdo depositado em recipiente público. Não há que se falar, nesse caso, em violação à intimidade, uma vez que a própria pessoa abriu mão de sua privacidade ao se desfazer do lixo ${ }^{64}$. No que diz respeito ao segundo, com o intuito de obter material gráfico para realização de exame, poderá a autoridade requisitar documentos em órgãos ou repartições públicas e privadas, bem como proceder à busca e apreensão de manuscritos na residência ou trabalho do investigado. É que, nesses casos, não há qualquer constrangimento ou obrigação de fazer ou não fazer por parte do investigado que fira direito seu a dispor do próprio corpo.

Cumpre por fim destacar que autodefesa negativa é renunciável, podendo o investigado optar pela autodefesa positiva, ou seja, contribuir com materiais, documentos ou informações para afastar a imputação que recai sobre ele (LOPES JUNIOR, 2010; SAAD, 2004). Contudo, há que se esperar que ônus de provar o fato não seja transferido para o investigado/acusado e que a acusação busque provas que não dependam da colaboração do acusado para demonstrar os fatos (QUEIJO, 2003).

\section{Consideraçốes Finais}

Como ressaltado na introdução, a atuação de toda instituição pública deve estar fundada na eficácia tanto na eficácia técnica quanto jurídica, a fim de assegurar a realização de um processo penal justo.

produzida com as mesmas garantias da prova antecipada; e) existir decisão judicial fundamentada (idem, 2003).

64 Nesse sentido é a posição de Carvalho (2004, p. 70). 
Assim, resta claro que as instituições responsáveis pela persecução penal devem saber quando podem ou não agir na busca da prova (prova proibida ou ilícita) ou como deve investigar (prova inútil, desproporcional), sempre levando em conta os limites de sua atuação frente a direitos individuais garantidos (escuta telefônica - privacidade; ingerências corporais - incolumidade física; busca domiciliar — inviolabilidade do domicílio).

Em outras palavras, a eficácia jurídica da gestão da prova deve ser o objetivo principal das autoridades que dirigem a persecução extrajudicial ou judicial, bem como daquelas que participam ativamente na instrução criminal e não a busca sem limites de uma verdade inatingível.

O mito da verdade real, de cunho nitidamente autoritário, esmoreceu diante dos postulados garantistas do Estado de direito. As limitações derivadas do devido processo legal e das garantias dele decorrentes (inadmissibilidade da prova ilícita, ampla defesa, contraditório, direito ao silencio, a não ser obrigado a produzir prova contra si mesmo entre outros) demonstram que a verdade processual é somente e tão-somente aquela possível, atingível nos estreitos limites da legalidade ou com a colaboração do investigado (autodefesa positiva).

Conclui-se, portanto, que na investigação do crime não vale tudo. A construção da verdade deve estar pautada por critérios racionais de legalidade e justiça, de modo a que os direitos fundamentais da pessoa humana sejam respeitados, não apenas pelas partes do processo, mas também pelos órgãos responsáveis pela instrução probatória durante a investigação criminal ou instrução criminal em juízo.

EMERSON Silva BARbosa

Mestre e doutorando em Direito pela Universidade De Brasília - UnB. Possui Pós-graduação Lato SENSU (especialização) em Direito Civil e Processo Civil. Atualmente é Delegado de Polícia Federal, com atuação nas Áreas de ensino e pesquisa na Academia Nacional Polícia 


\title{
Constitutional Limits on the Evidence in Criminal investigation
}

\begin{abstract}
This paper seeks to expose and discuss the constitutional limits on the evidence in the Brazilian criminal proceedings. The intent here is to address the problems arising from the legality of evidence under a negative outlook - the prohibition of illegal evidence use. We intend to address the achievement of evidence in situations that require the removal of fundamental rights such as intimacy or privacy and body integrity.
\end{abstract}

KEYwORDS: Evidence. Illegal evidence. Criminal proceedings.

\section{Límites Constitucionales para Prueba en Investigación Penal}

\section{RESUMEN}

Es un trabajo que busca exponery discutir los límites constitucionales de las pruebas en el proceso penal brasileño. La intención aquí es hacer frente a los problemas derivados de la legalidad de la prueba bajo una perspectiva negativa - la de la prohibición del uso de la prueba ilegal. Tenemos la intención de hacer frente a la obtención de pruebas en situaciones que requieren el afastamiento de los derechos fundamentales tales como la privacidad o la intimidad y la integridad corporal.

Palabras Clave: Prueba. Prueba ilegal. Devido proceso penal.

\section{REFERÊNCIAS}

ALEXY, Robert. Teoria dos direitos fundamentais. Trad. Virgílio Afonso da Silva. $5^{\text {a }}$ edição. São Paulo: Malheiros, 2008.

ARANHA, Adalberto José Q. T. Camargo. Da prova no processo penal. $7^{\text {a }}$ ed. Saraiva: São Paulo, 2006.

BADARÓ, Gustavo Henrique Righi Ivahy. Ônus da prova no processo penal. São Paulo: RT, 2003.

BARBOSA, Emerson Silva. O devido processo penal e as garantias do contraditório e ampla defesa no inquérito policial. Revista Sistema Penal \& Violência, Porto Alegre, v. 3, n. 1, p. 74-88, jan./jun. 2011. 
- Sistema de prova no direito brasileiro e a obrigatoriedade do exame do de corpo de delito. In: Âmbito Jurídico, Rio Grande, XIV, n. 88, maio 2011. Disponível em: <http://www.ambito-juridico.com.br/ site/index.php?n_link=revista_artigos_leitura\&artigo_id=9432>. Acesso em jul 2012.

BINDER, Alberto M. Introducción al derecho procesal penal. $2^{\mathrm{a}} \mathrm{ed}$. Buenos Aires: Ad hoc, 1999.

BONFIM, Edilson Mougenot. Código de processo penal anotado. $2^{\mathrm{a}} \mathrm{ed}$. São Paulo: Saraiva, 2009.

BULOS, Uadi Lammêgo. Constituição federal anotada. $9^{a}$ edição. rev. e atual. até a EC ñ 57/2008. São Paulo: Saraiva, 2009.

CAFFERATA NORIS, Jose I. La prueba en el processo penal. $3^{a}$ edição. Actualizada y ampliada. Buenos Aires: Depalma, 1998.

CARVALHO, Luis Gustavo Grandinetti Castanho de. Processo penal e (em face) Constituição: Princípios constitucionais do processo penal. $3^{a}$ edição, reescrita e ampliada. Rio de Janeiro: Lúmen Júris, 2004.

CHOURK, Fauzi Hassan. Garantias constitucionais na investigação criminal. $3^{a}$ edição, ampl. e atual. Rio de Janeiro: Lúmen Júris, 2006.

COLOMER, Juan-Luis Gómez et al. Polícia e Estado democrático de direito na América Latina. Rio de Janeiro: Editora Lúmen Júris, 2004.

CORREA, Silvia Leme. A prova processual penal ilícita e a teoria da proporcionalidade. 2006. 150f. Dissertação (Mestrado em direito). Universidade Federal do Paraná, Curitiba, 2006.

CUNHA JÚNIOR, Dirley da. Curso de direito constitucional. Salvador: JusPODIVM, 2008.

FERNANDES, Antônio Scarance. Processo penal constitucional. $3^{\mathrm{a}}$ edição. Rev. atual. e ampliada. São Paulo: Editora Revista dos Tribunais, 2002.

FERRAJOLI, Luigi: Direito e Razão: teoria do garantismo penal. São Paulo: RT, 2002.

FERRI, Enrico. Princípios de direito criminal. $3^{a}$ ed. Trad. Luiz de Lemos D’Oliveira. Campinas: Russel Editores, 2009. 
FRAGOSO, Tomás López. Los descubrimientos casuales en las intervenciones telefónicas como medidas coercitivas en el proceso penal. Derechos y Libertades. (2). Oct 1993-mar 1994, p.81-90.

LANGBEIN, John H., The criminal trial before the lawyers. Faculty Scholarship Series. (1978). Paper 542. http://digitalcommons.law. yale.edu/fss_papers/542. Acessado em 02/06/2012.

LEA, John; YOUNG, Jock. ¿Qué hacer con la ley e el orden? Trad. Mariano Ciafardini. Buenos Aires: Del Puerto, 2008.

LOPES JR., Aury. Introdução crítica ao processo penal: fundamentos da instrumentalidade constitucional. $5^{\text {a }}$ edição. Rio de Janeiro: Lumen Juris, 2010.

MAcCORMICK, Neil. Retórica e estado de direito. Trad. Conrado Hubner Mendes. Rio de Janeiro: Elsevier, 2008.

MENDES, Gilmar Ferreira et. al. Curso de direito constitucional. $5^{a}$ edição. São Paulo: Saraiva, 2010.

MORAES, Alexandre de. Direito constitucional. 22a ed. Atualizado até a EC no 53/06. São Paulo: Atlas, 2007.

BONFIM, Edilson Mougenot. Código de processo penal anotado. $2^{\mathrm{a}} \mathrm{ed}$. São Paulo: Saraiva, 2009.

NETTO, Andre Luiz Borges. A razoabilidade constitucional (o princípio do devido processo legal substantivo aplicado a casos concretos). Revista Jurídica Virtual do Palácio do Planalto, vol. 2, no 12 Maio/2000. Extraído de http://www.planalto.gov.br/CCIVIL/ revista/Rev_12/razoab_const.htm. Acessado em 10/05/2010.

NUCCI, Guilherme de Souza. Manual de processo e execução penal. São Paulo: RT, 2005.

OLIVEIRA, Eugênio Pacelli. Curso de processo penal. $8^{\mathrm{a}} \mathrm{ed}$. Rio de Janeiro: Lumen Juris, 2007.

QUEIJO, Maria Elizabeth. O direito de não produzir prova contra si mesmo: o princípio nemo tenetur se detegere e suas decorrências no processo penal. São Paulo: Saraiva, 2003.

SAAD, Marta. O direito de defesa no inquérito policial. São Paulo: 
Revista dos Tribunais; 2004. Coleção estudos de processo penal Joaquim Canuto Mendes de Almeida: v. 9.

SILVA, José Afonso da. Curso de direito constitucional positivo. 29a edição. Rev. e atualizado até a EC nº 53/2006. São Paulo: Malheiros, 2007.

TEDESCO, Ignacio F. La libertad de la declaración del imputado: un análisis histórico-comparado. In: Las garantías penales y procesales: un enfoque histórico-comparado. Luís Bunge Campos et. al. Buenos Aires: Editores del Puerto, 2004.

TUCCI, Rogério Lauria. Direitos e garantias individuais no processo penal brasileiro. $3^{\text {a }}$ edição. Rev., atual. e ampliada. São Paulo: Editora Revista dos Tribunais, 2009.

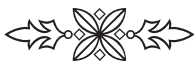

